ISSN1027-5495. Functional Materials, 24, No.1 (2017), p. 76-81

\title{
Fabrication and mechanical performance of 3D woven basalt fiber composite materials
}

\author{
Lihua Lv, Xuefei Zhang, Fang Ye, Yongfang Qian, \\ Yuping Zhao, Guibin Liu
}

\author{
Department of Textile Engineering, Dalian Polytechnic University, \\ Dalian, P.R.China
}

Received December 25, 2016

\begin{abstract}
Three kinds differently structural 3D woven fabrics with the basalt fiber filaments tows as warp and weft yarn were fabricated on common loom by reasonable design. And, three kinds differently structural 3D woven basalt fiber composite materials were obtained with vinyl ester resin as matrix materials and 3D woven fabrics as reinforced materials, by VARTM molding process (vacuum assisted resin transfer molding process). Then, the tensile and bending properties of three kinds differently structural 3D woven basalt fiber composite materials were tested through the universal testing machine. Results were shown that the 3D woven basalt fiber composite materials had excellent mechanical properties, but the different structures of 3D woven fabrics as reinforced materials shown a big difference on mechanical properties. As follows, the modulus of elasticity for tensile and modulus of elasticity for bending of the 3D orthogonal structure basalt fiber composite materials were the greatest, and that of the 3D throughout angle interlocking structure basalt fiber composite materials was the smallest. Meanwhile, the tensile elongation at break of the 3D throughout angle interlocking structure basalt fiber composite materials were the largest and that of the 3D layered angle interlocking structure basalt fiber composite materials was the smallest.

Keywords: woven basalt, composite materials.
\end{abstract}

Исследованы три вида по-разному структурированных 3D тканных волокон с базальтовыми нитями. Методом VARTM (инжекция связующего в закрытую форму с помощью вакуума) 3D тканые композитные материалы из базальтового волокна были получены из виниләстеровой смолы (матрица материала) и 3D ткани (армирующий материал). Исследованы их свойства на растяжение и изгиб. Результаты показали, что по-разному структурированные 3D сплетенные из базальтового волокна композиционные материалы имели отличные механические свойства и различные структуры 3D ткани. Показано, что модуль упругости на растяжение и модуль упругости на изгиб 3D ортогональной структуры базальтового волокна композитных материалов были самыми большими, а в 3D структурах углового сплетения базальтового волокна композитных материалов они были самыми малыми.

Виготовлення та механічні характеристики 3D тканного базальтового волокна композитних матеріалів. Л. Лихуа, Сюэфей Чжан, Є. Фан, Юнфбан Цянь, Юйпин Чжао, Лю Гуибинь. Досліджено три види по-різному структурованих 3D тканих волокон з базальтовими нитками. Методом VARTM (інжекція сполучного в закриту фрорму за допомогою вакууму) 3D ткані композитні матеріали з базальтового волокна були отримані 3 вінілестерової смоли (матриця матеріалу) і 3D тканини (армуючий матеріал). Досліджено їх властивості на розтягнення і вигин. Результати показали, що по-різному структуровані 3D сплетені з базальтового волокна композиційні матеріали мали відмінні механічні властивості i різні структури 3D тканини. Показано, що модуль пружності на розтяг і модуль пружності при вигині 3D ортогональної структури базальтового волокна композитних матеріалів були найбільшими, і що в 3D структурах кутового сплетення базальтового волокна композитних матеріалів вони були найменшими. 


\section{Introduction}

Laminated composite materials have been used in structural applications since the 1960s. However, their cost is high and inability to accommodate fibers in the laminate`s thickness direction greatly reduce their damage tolerance and impact resistance. 3D textile reinforced composites offer significant cost reduction, and incorporating reinforcement in the thickness direction increases damage tolerance and impact resistance dramatically.

$3 \mathrm{D}$ woven composite materials with $3 \mathrm{D}$ woven fabric as reinforced materials and resin as matrix materials are a kind of $3 \mathrm{D}$ textile structural composites[1-2]. The warp and weft yarns in woven fabric provide the highest in-plane stiffness and strength, while the "Z-direction" yarn acrossing the thickness direction can provide the stability of composite materials. The excellent integrality of $3 \mathrm{D}$ woven composites shows better delamination resistance and damage tolerance [3-4],therefore they are used widely in engineering, aerospace, sports equipment, automobile, architecture [5-6].

As the increasing application of $3 \mathrm{D}$ woven composites in engineering, a number of studies on mechanical properties of $3 \mathrm{D}$ woven composites have been done. The mechanical models of $3 \mathrm{D}$ woven composites were set up to analyze its mechanical properties and the failure mode under tensile and shear loading by Naik and Lee's[7-9] . Sun et al.[10] tested UHMWPE/Vinyl Ester 2.5D angle interlock woven composite materials in compression performance and discussed the compression failure mode and failure mechanism. Rong [11]conducted the tensile and compressive tests on ultra-thick 3D orthogonal woven composites and the tensile and compressive strength of $3 \mathrm{D}$ orthogonal woven composites were better than that of $2 \mathrm{D}$ woven laminates.

In the above studies, only a kind of structure $3 \mathrm{D}$ woven composites was selected as research object. In order to evaluate the effect of fabric structures on mechanical properties, three kinds differently structural 3D woven fabrics with the basalt fiber filaments tows which has excellent mechanical properties and is environmental friendly[12-13] as warp and weft yarn were fabricated on common loom. And, three kinds differently structural 3D woven basalt fiber composite materials were obtained with vinyl ester resin as matrix materials and 3D woven fabrics as reinforced materials by Vacuum Aided Resin Transfer Molding (VARTM) technique. And the tensile and bending properties of the materials were tested through the universal testing machine. Then the mechanical properties of the three kinds differently structural 3D woven basalt fiber composite ma- terials have been made comparative analysis. This study not only provides evidence for the selection of materials for people under different demand, but also provides reference for the optimization design of the mechanical properties of $3 \mathrm{D}$ woven fabric composite materials.

\section{Experimental}

\subsection{Experimental materials and equip- ment}

600tex basalt fiber, 1200 tex basalt fiber, vinyl ester resin, methyl ethyl ketone peroxide, octylic acid cobalt.

Loom for weaving small sample in the lab (Y100S),VARTM molding system, universal system prototype (NHY-W), microcomputer control electronic universal testing machine (RGT-5), muffle furnace (SX2).

\subsection{Design and weaving of three kinds differently structural $3 D$ woven fabrics}

In this paper, the twist basalt fiber filaments tows with 600tex were employed as warp yarns, and the twistless basalt fiber filaments tows with 1200tex were employed as weft yarns. The design of the fabrics was referenced to literature [14], by the warp structural diagram, as shown in figure 1 . The fabric organization charts of three kinds differently structural 3D woven fabrics were shown in figure 2 according to figure 1 .

\subsection{Fabrication of $3 D$ woven basalt fi-} ber composite materials

VARTM (Vacuum Assisted Resin Transfer Molding) Molding technique was used to fabricate $3 \mathrm{D}$ woven basalt fiber composite materials. The role of its principle and structure of each part could be seen in literature [15].

\subsection{Testing of $3 D$ woven basalt fiber composite materials}

\subsubsection{Testing of tensile properties}

The testing of tensile properties was according to GB/T1447-2005, and the universal system prototype (NHY-W) was used to prepare testing samples which were obtained from composite materials in warp and weft direction. Then the samples were tested on the microcomputer control universal testing machine (RGT-5).

\subsubsection{Testing of bending properties}

The testing of bending properties was according to GB/T1449-2005, and the universal system prototype (NHY-W) was used to prepare testing samples which were obtained from composite materials in warp and weft direction. Then the samples were tested on the microcomputer control universal testing machine (RGT-5). 


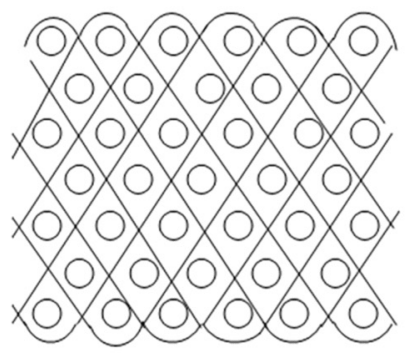

throughout angle interlocking structure

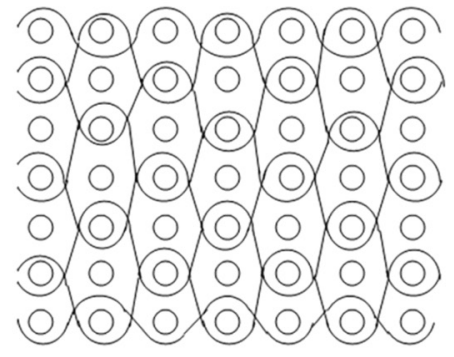

layered angle interlocking structure

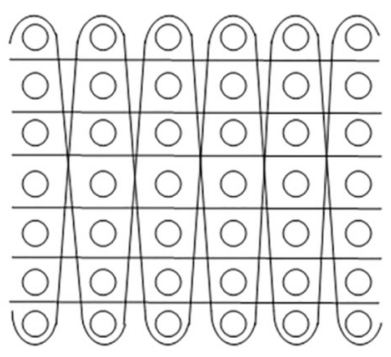

orthogonal structure

Fig.1. Warp structural diagram of three kinds differently structural 3D woven fabrics

\subsubsection{Testing of fiber volume fraction}

The testing of fiber volume fraction was according to GB/T 2577-2005, and a muffle furnace (SX2) was used for burning.

\section{Results and discussion}

\subsection{Mechanical properties of three kinds differently structural $3 D$ woven ba- salt fiber composite materials}

\subsubsection{Tensile properties}

The warp and weft direction tensile stressstrain curves of three kinds differently structural 3D woven basalt fiber composite materials were shown in Figure 3.

It could be seen many similar trends among the tensile stress-strain curves of three kinds differently structural 3D woven basalt fiber composite materials. The tensile stress-strain curves could be divided into three phases. At the beginning, stress-strain curves of the three kind materials were almost linear both in warp and weft direction. This indicated that the bonding situation was also good between resin and fiber. That was to say the resin and fiber was good enough to combine into a whole, so that the materials shown out linear elastic performance. The different slopes of the straight lines reflected differences modulus of elasticity of the different composites. The second phase was as follows, as the tensile stress continued to be increased, the curves no longer presented straight lines, and the curves slope was reduced. The reason was that at this time the $3 \mathrm{D}$ woven fabric as the reinforced materials beared the main tensile stress. And as the result of the flexibility of 3D woven fabrics, 3D woven basalt fiber composite materials shown out apparent plastic deformation, and the deformation was more easily occurred than the previous stage, so the stress-strain curves were gentle rise trends. The third phase was the descending branch. When the load reached the maximum, the basalt fiber filaments tows began to be damaged and the curves emerged falling trend.

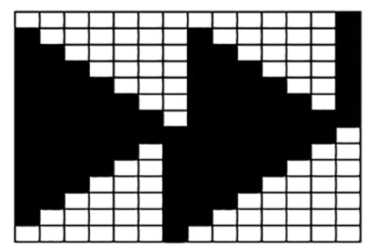

orthogonal structure

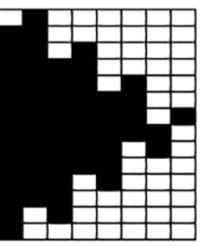

layered angle interlocking structure

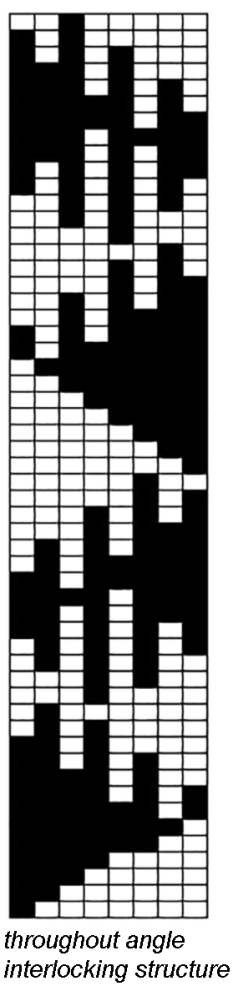

Fig.2. Organization charts of three kinds differently structural 3D woven fabrics

In the tensile stress-strain curves, there were many differences, too. In 3D orthogonal structure basalt fiber composite materials, the warp and weft filaments tows were completely straight, and only the bundling filaments tows in the thickness direction were curving, so the tensile stress-strain curves was swift declining. Compared with 3D orthogonal structure basalt fiber composite materials, the filaments tows were twisted much more in the 3D layered angle interlocking structure and 3D throughout angle interlocking structure basalt fiber composite materials, so they had stronger buffer ability against the tensile stress, especially the 3D throughout angle-interlock structure basalt fiber composite materials. So tensile stressstrain curves appeared slow decline. 


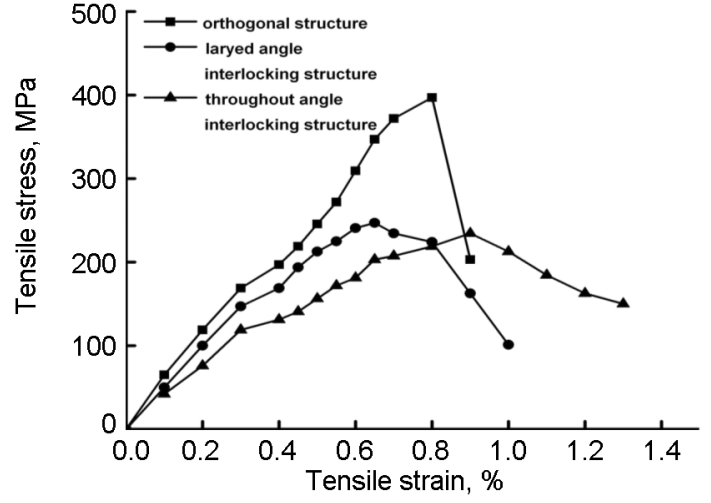

a) Warp direction

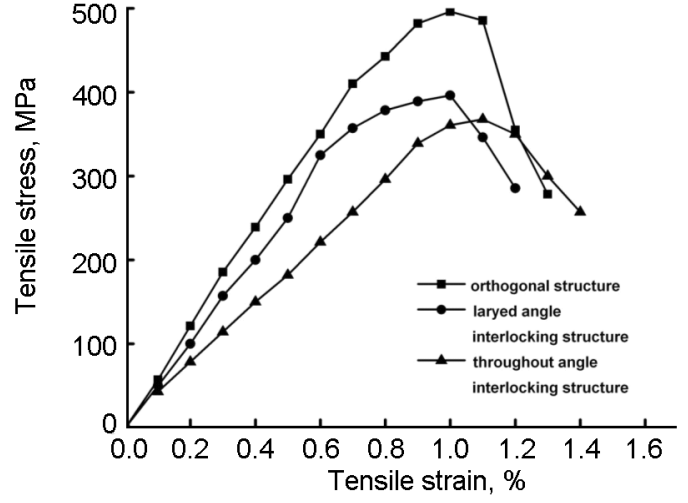

b) Weft direction

Fig.3. Warp and weft tensile stress-strain curves of three kinds differently structural 3D woven basalt fiber composite materials

What's more, there were also significant differences between the warp and weft direction tensile stress-strain curves of three kinds differently structural 3D woven basalt fiber composite materials. First of all, the tensile stress of the weft direction was much higher than that of the warp direction, this was because the weft filaments tows linear density was greater. Secondly, the curving of filaments tows in the warp direction was more than that in the weft direction. So, in the tensile testing, buffering capacity of the warp direction was stronger, and the buffer strain in the warp direction was bigger than that in the weft direction in tensile stress-strain curves. Then, in the tensile testing, the failure mode of the $3 \mathrm{D}$ woven basalt fiber composite materials was including resin crack, fiber breakage, debonding and pulled up, as shown in figure 4.

\subsubsection{Bending performance}

The warp and weft direction bending stressdeflection curves of three kinds differently structural 3D woven basalt fiber composite materials were shown in figure 5 .

As same as the tensile stress-strain curves, there were also similar trends showing in the warp and weft direction bending stress-deflection curves. At first, the bending stress-deflection curves appeared a straight line both in warp and weft direction. This was to say, the whole materials shown out linear elastic performance. With the increase of the bending stress, the resin began to be destroyed, at this time 3D woven fabric as the reinforced materials beared the main bending stress and still had a lot of stress tolerance, so the curves was continue to rise gently. And the buffer displacements were very big, this was because the $3 \mathrm{D}$ woven fabrics had good flexibility. what's more, it was obviously that the buffer displacements of the warp direction were greater than that of the weft direction, this was because the curving

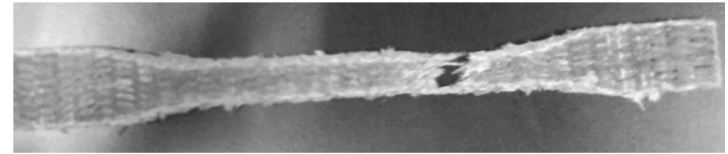

Fig.4. Photographs of tensile failure mode

of filaments tows in the warp direction was far more than that in the weft direction. And in the loading process, the filaments tows in the warp direction had to become straight little by little. When the load reached the maximum, the fiber filaments tows in the composites began to fracture. And, bending stress-deflection curves appeared a downward trend.

The curves of the $3 \mathrm{D}$ throughout angle interlocking structure basalt fiber composite materials declined slowly. However, the curves of 3D orthogonal structure basalt fiber composite materials declined sharply, especially in the weft direction. This was due to the relatively poor bonding force between the layers, and filaments tows in the $3 \mathrm{D}$ orthogonal structure basalt fiber composite materials was more straight, so that they were beared the stress evenly. In addition, the bending stress in the weft direction was greater than that in the warp direction, this was also because the linear density of filaments tows in weft direction was greater than that in the warp direction. In the bending test, bending failure mode was compressed failure on the top surface, and stretched failure on the below surface. On the top surface, the resin appeared white and cracked, and parts of the fiber filaments tows were arch. On the below surface, the fiber filaments tows were pulled off. But, in the whole test process, the samples had no obvious fracture and split phenomenon as shown in figure 6 . 


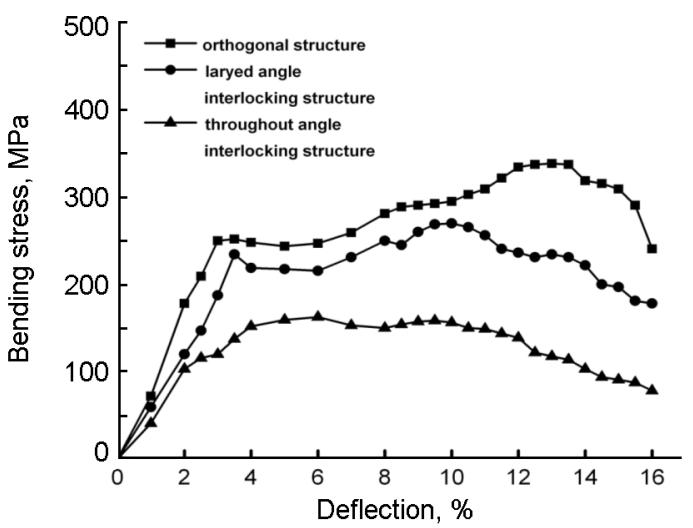

a) Warp direction

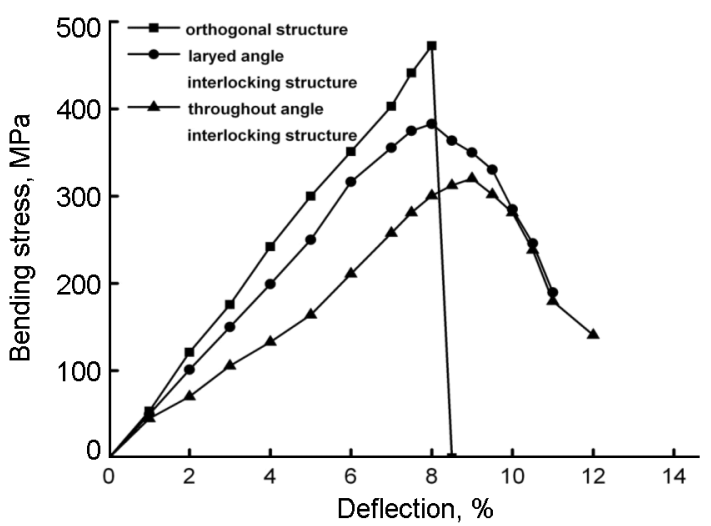

b) Weft direction

Fig.5. Warp and weft bending strength-deflection curves of three kinds differently structural 3D woven basalt fiber composite materials

\subsection{Comparison of three kinds differ- ently structural 3D woven basalt fiber composite materials}

3.2.1 Fiber volume fraction of three kinds differently structural $3 D$ woven basalt fiber composite materials

The testing of fiber volume fraction was according to GB/T 2577-2005. It was shown that the fiber volume fraction was different for 3D woven basalt fiber composite materials for the different structures. This signally effected on the mechanical properties of $3 \mathrm{D}$ woven basalt fiber composite materials. The fiber volume fraction of the 3D orthogonal structure basalt fiber composite materials was $45.7 \%$, the fiber volume fraction of the 3D layered angle interlocking structure basalt fiber composite materials was $42.6 \%$, and the $3 \mathrm{D}$ throughout angle interlocking structure basalt fiber composite materials was only $36.4 \%$.

3.2.2 Comparison of mechanical properties for three kinds differently structural 3D woven basalt fiber composite materials.

Table 1 was the parameters of mechanical properties of three kinds differently structural
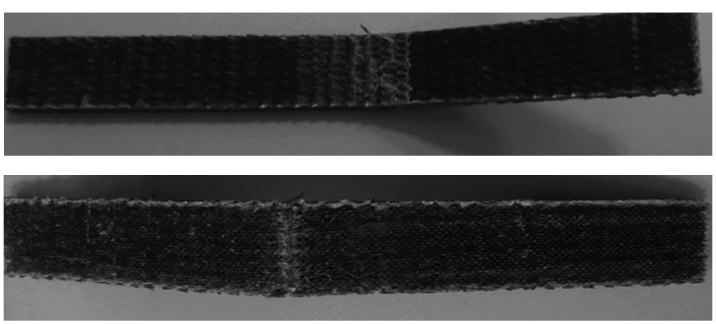

Fig.6. Photographs of bending failure mode(top and below)

3D woven basalt fiber composite materials. It could be seen from the table that the tensile stress of the $3 \mathrm{D}$ orthogonal structure basalt fiber composite materials was the strongest, that of 3D throughout angle interlocking structure basalt fiber composite materials was more stronger, and 3D layered angle interlocking structure basalt fiber composite materials was the worst. This was because the warp and weft filaments tows were completely straight materials and only the bundling filaments tows in the thickness direction were curving in $3 \mathrm{D}$ orthogonal structure basalt fiber composite. And during tensile process, 3D orthogonal woven

Table 1. Parameters of mechanical properties of three kinds differently structural 3D woven basalt fiber composite materials

\begin{tabular}{|c|c|c|c|c|c|c|c|c|c|c|}
\hline \multirow[t]{2}{*}{ fabric construction } & \multicolumn{2}{|c|}{$\begin{array}{c}\text { tensile stress/ } \\
\mathrm{Mpa}\end{array}$} & \multicolumn{2}{|c|}{$\begin{array}{l}\text { tensile modulus } \\
\text { of elasticity / } \\
\text { Gpa }\end{array}$} & \multicolumn{2}{|c|}{$\begin{array}{c}\text { tensile elonga- } \\
\text { tion at break } \\
1 \%\end{array}$} & \multicolumn{2}{|c|}{$\begin{array}{c}\text { bending } \\
\text { strength/ Mpa }\end{array}$} & \multicolumn{2}{|c|}{$\begin{array}{l}\text { bending } \\
\text { modulus of } \\
\text { elasticity } \\
\text { /Gpa }\end{array}$} \\
\hline & warp & weft & warp & weft & warp & weft & warp & weft & warp & weft \\
\hline orthogonal structure & 389.81 & 493.33 & 16.86 & 18.71 & 1.51 & 1.38 & 376.27 & 464.58 & 17.66 & 20.59 \\
\hline $\begin{array}{l}\text { layered angle inter- } \\
\text { locking structure }\end{array}$ & 249.55 & 393.01 & 13.65 & 15.96 & 1.35 & 1.23 & 229.76 & 381.43 & 12.09 & 18.71 \\
\hline $\begin{array}{l}\text { throughout angle in- } \\
\text { terlocking structure }\end{array}$ & 326.09 & 415.23 & 10.94 & 12.09 & 1.61 & 1.46 & 200.81 & 320.71 & 10.65 & 15.24 \\
\hline
\end{tabular}


fabric composites beared stress evenly, this was very beneficial for the composites to bear the tensile stress in the fiber direction. Then, in the three kinds of composites, 3D orthogonal woven fabric composites had the biggest fiber volume fraction as seen from the fiber volume fraction. So, the more fiber could beared the tensile stress, and the tensile stress was the bigger. Although the fiber volume fraction of the 3D layered angle interlocking structure was higher than that of the $3 \mathrm{D}$ throughout angle interlocking structure, the tensile stress of the 3D layered angle interlocking structure was the lowest due to the worst consistency of fiber filaments tows buckling.

As for the bending stress, it was mainly affected by fiber volume fraction. Among three kinds differently structural 3D woven basalt fiber composite materials, fiber volume fraction of the $3 \mathrm{D}$ orthogonal structure was the largest, and that of the 3D throughout angle interlocking structure was the smallest.

Elastic modulus reflected the deformation ability of the materials during the initial period, and the modulus was greater, the material was more difficult to deformation. It was mainly affected by fiber volume fraction, also. In fiber volume fraction, among three kinds differently structural 3D woven basalt fiber composite materials, fiber volume fraction of the 3D orthogonal structure was the largest, and that of the 3D throughout angle interlocking structure was the smallest. So, the tensile and bending modulus of elasticity of 3D orthogonal structure was the biggest and the that of $3 \mathrm{D}$ throughout angle interlocking structure was the minimum.

The tensile elongation at break of the 3D throughout angle interlocking structure composite was the biggest and this was because the fiber bucking and the consistency of fiber buckling was good. And, the tensile elongation at break of the 3D layered angle interlocking structure composite was the smallest due to the worst consistency of fiber buckling and uneven force.

\section{Conclusion}

By reasonable design, the 3D woven fabrics as the reinforced materials can be finished on common loom.

The 3D woven basalt fiber composite materials have excellent mechanical properties. In the test process, the materials show out good interlaminar shear stress, no delamination and splitting phenomenon, and the stress buffering capacity was strong.

The structures of the 3D woven fabrics as the reinforced materials were different, the mechanical properties of composite materials made of 3D woven fabrics also show a big difference. Among the three kinds differently structural 3D woven basalt fiber composite materials studied in this paper, the 3D orthogonal structure composites have the biggest tensile modulus of elasticity and bending modulus of elasticity, while the 3D throughout angle interlocking structure composites had the smallest. As for the tensile elongation at break, the 3D throughout angle interlocking structure composite was the biggest and the 3D layered angle interlocking structure composite was the smallest.

\section{Acknowledgements}

The authors gratefully acknowledge financial support from the National Science Foundation of Liaoning Province (201602051).

\section{References}

1. H.L.Yi, Adv.mech. ,31,161, 2001.

2. C.Y. Yang, Z.Y.Hu, H.Y.Zhou, J.Mater.Eng., 30(9), 29, 2009.

3. C.G. Ji, , Fiber Comp., 24, 48, 2007.

4. J.Wang, C.Y.Zhu., J. Mater.Eng. ,Z1, 179, 2007.

5. W.S. Kuo, Comp. Part A-Appl.S., 34(7), 561, 2003.

6. P.Tan, L.Tong, G. P. Steven et al., Comp.Part AAppl.S., 31(99), 259, 2000.

7. N.K.Naik, S. N. M. Azad, P. D. P.And et al, J.Reinf. Plast .Comp., 20(17), 1485, 2001.

8. N.K.Naik, E.Sridevi, J.Reinf. Plast. Comp., 21 (13), 1149, 2002.

9. C.S.Lee, J.Comp.Mater.,39(10), 851, 2005.

10. Y.Sun,G. J.Wang, D.T.Zhang et al., J. Mater. Eng., 1(4), 38, 2011.

11. R.Qi., Fiber Comp.,1,31, 2007.

12. E.G.Xie, Z.Y. Li,Fiber comp., 20, 17, 2003.

13. L.X.Jia, X.Z.Jiang, L.V.Lei et al., Fiber comp., 22, 13, 2005.

14. L.H. Lv, C.Y. Wei, X.Zhao, X.N. Li, Cotton Textile Techn., 39(9), 552, 2011.

15. X.B.LI , Z.H.Sun, Z.H.Cao, Thermosetting Resin, 21, 39, 2006 